University of Nebraska - Lincoln

DigitalCommons@University of Nebraska - Lincoln

U.S. National Park Service Publications and

Papers

National Park Service

$5-8-2020$

Development of a modified floristic quality index as a rapid habitat assessment method in the northern Everglades

Rebakah E. Gibble

U.S. Fish and Wildlife Service, rebekah_gibble@fws.gov

Donatto D. Surratt

Everglades National Park, National Park Service

Follow this and additional works at: https://digitalcommons.unl.edu/natlpark

Part of the Environmental Education Commons, Environmental Policy Commons, Environmental Studies Commons, Fire Science and Firefighting Commons, Leisure Studies Commons, Natural Resource Economics Commons, Natural Resources Management and Policy Commons, Nature and Society Relations Commons, Other Environmental Sciences Commons, Physical and Environmental Geography Commons, Public Administration Commons, and the Recreation, Parks and Tourism Administration Commons

Gibble, Rebakah E. and Surratt, Donatto D., "Development of a modified floristic quality index as a rapid habitat assessment method in the northern Everglades" (2020). U.S. National Park Service Publications and Papers. 202.

https://digitalcommons.unl.edu/natlpark/202

This Article is brought to you for free and open access by the National Park Service at DigitalCommons@University of Nebraska - Lincoln. It has been accepted for inclusion in U.S. National Park Service Publications and Papers by an authorized administrator of DigitalCommons@University of Nebraska - Lincoln. 


\title{
Development of a modified floristic quality index as a rapid habitat assessment method in the northern Everglades
}

\author{
Rebekah E. Gibble • Donatto D. Surratt
}

Received: 9 December 2019 / Accepted: 21 April 2020

(C) This is a U.S. government work and not under copyright protection in the U.S.; foreign copyright protection may apply 2020

\begin{abstract}
Floristic quality assessments (FQA) using floristic quality indices (FQIs) are useful tools for assessing and comparing vegetation communities and related habitat condition. However, intensive vegetation surveys requiring significant time and technical expertise are necessary, which limits the use of FQIs in environmental monitoring programs. This study modified standard FQI methods to develop a rapid assessment method for characterizing and modeling change in wetland habitat condition in the northern Everglades. Method modifications include limiting vegetation surveys to a subset of taxa selected as indicators of impact and eliminating richness and/or abundance factors from the equation. These modifications reduce the amount of time required to complete surveys and minimizes misidentification of species, which can skew results. The habitat characterization and assessment tool (HCAT) developed here is a FQA that uses a modified FQI to detect and model changes in habitat condition based on vegetation communities, characterize levels of impact as high, moderate, or low, provide predictive capabilities for assessing natural resource management or water management operation alternatives, and uniquely links a FQI with readily accessible environmental data. For
\end{abstract}

\author{
R. E. Gibble $(\bowtie)$ \\ U.S. Fish and Wildlife Service, 10216 Lee Rd., Boynton Beach, \\ FL 33473, USA \\ e-mail: rebekah_gibble@fws.gov \\ D. D. Surratt \\ Everglades National Park, National Park Service, Boynton Beach, \\ FL, USA
}

application in the northern Everglades, surface water phosphorus concentrations, specific conductivity, distance from canal, and days since dry (5-year average) explained $67 \%$ of the variability in the dataset with > $99.9 \%$ confidence. The HCAT approach can be used to monitor, assess, and evaluate habitats with the objective of informing management decisions (e.g., as a screening tool) to maximize conservation and restoration of protected areas and is transferable to other wetlands with additional modification.

Keywords HCAT · A.R.M. Loxahatchee National Wildlife Refuge $\cdot$ Floristic quality index $\cdot$ Floristic quality assessment $\cdot$ Coefficient of conservatism $\cdot$ Wetland condition

\section{Introduction}

Plant communities are indicators of ecological integrity because of their rapid growth rates, sensitivity to environmental stressors, and their role as the foundation of habitats (Cohen et al. 2004; Smith et al. 1995; USEPA 2002). Floristic quality assessment (FQA) tools use existing plant communities to objectively and reliably assess and/or compare habitats spatially and/or temporally (e.g., Nichols et al. 2006; Taft et al. 1997; Herman et al. 1997; Wilhelm and Masters 2006a, b; Cretini et al. 2012). Floristic quality assessment tools, such as Floristic Quality Indices (FQI), are typically based on coefficient of conservatism values (CC), which are published sets of quantitative values that serve as indicators of 
fidelity of individual species to a particular site or set of conditions. These tools have been used with increasing frequency for quantitatively assessing habitat condition of public lands (Bourdaghs 2012) and have been included in monitoring programs for by federal and state land managers, including the US Environmental Protection Agency, US Army Corps of Engineers, US Geological Survey (USGS) Minnesota Pollution control agency, and Louisiana Coastal Protection and Restoration Authority.

Typical FQAs use intensive and repeated field surveys to derive FQIs from average $\mathrm{CC}$ and site richness values. The resulting site-specific FQI values can be compared across space and time within and between sites to determine changes in the severity and/or spatial extent of impact from stressors such as elevated phosphorus levels from adjacent land use. Disadvantages of typical FQIs include the need for intensive and repeated plant surveys, as well as the significant potential for misidentification of species because of the requirement to identify all plants to the species level (Johnston et al. 2008). Typical FQIs used in FQAs include a site richness factor. However, earlier studies indicate that average $\mathrm{CC}$ values as an index score are a more reliable indicator of site condition and can be adequately calculated with minimal and controlled sampling effort (Rooney and Rogers 2002; Bourdaghs et al. 2006). Further, common and easy to identify species have been found to be the main drivers of typical FQI results, and limiting surveys to those species did not significantly change the interpretability of FQI scores (Lopez and Fennessey 2002; Johnston et al. 2008; Bourdaghs 2012; Chamberlain and Brooks 2016). Several studies concluded that including species richness in FQI calculations can bias the results because richness is strongly influenced by sampling effort (Francis et al. 2000; Matthews 2003; Rooney and Rogers 2002; Taft et al. 1997). Further, Miller and Wardrop (2006) found metrics such as species richness and diversity were not strongly correlated with disturbance and therefore do not likely provide significant benefit to tool sensitivity or accuracy. By eliminating species richness as a metric in the current study, the method could be applied as a rapid assessment method requiring minimal resources and training.

In this study, the habitat characterization and assessment tool (HCAT), a modified FQI and associated model was developed to monitor and predict the impact of adjacent land use and water management operations on the northernmost wetland of the remaining Everglades. Published coefficients of conservatism values (Mortellaro et al. 2009) and relatively little variability in seasonal plant distribution support the application of FQA tools in the Everglades. Large-scale restoration efforts in the Everglades have included substantial investment in monitoring and evaluating impacts and progress of projects meant to improve the structure and function of the Everglades, with a particular focus on vegetation communities (Ogden 2005).

While the Everglades landscape has high biodiversity, much of the diversity is at the landscape level and stems from a mosaic of patches of generally lower-diversity habitats, such as sawgrass ridges and wet prairies. The HCAT focuses on wetland taxa typically found in wet prairie habitats, which have higher diversity than some habitats, such as Cladiumdominated communities, but even wet prairie habitats tend to be dominated by a few species (e.g., E. elongata) or taxa, with rarer species spread throughout. The most impacted areas eventually transition to monotypic stands of Typha in some areas, as the result of increased nutrients and extended hydroperiods (Brown et al. 2006). Initial method development required selection of indicator taxa for the specific habitat and area being monitored using best professional judgment, available literature, and restoration goals. The taxa selected for the HCAT are common in the Everglades and have widespread distribution throughout the study site. Once developed, the HCAT provides a rapid habitat assessment and evaluation method using simple vegetation surveys that can be completed quickly by trained, nontechnical individuals. The tool significantly simplified standard FQA survey methods, reduced variability among samplers, and minimized species misidentification. Modeled index values link drivers of vegetation communities to changes in habitat quality and provides predictive capabilities to the tool.

In summary, development of the HCAT to characterize and assess impacts to northern Everglades marsh habitat required two steps as follows: (1) modification and validation of the typical FQI methods and (2) development and validation of a model that links vegetation community drivers with the modified FQI (step \#1). Combined, the modified FQI and model explaining the observed variability make up a tool (HCAT) for rapidly assessing and monitoring habitat quality in the northern Everglades. 


\section{Materials and methods}

Site description

Water levels in the Arthur R. Marshall Loxahatchee National Wildlife Refuge (Refuge; Fig. 1), like the rest of the Everglades, were historically driven by rainfall and sheet flow from Lake Okeechobee that resulted in seasonal fluctuations in water levels (Bernhardt and Willard 2009; Bernhardt et al. 2013). Elevation in the refuge marsh ranges from 3.2 to $5.6 \mathrm{~m} \mathrm{NGVD}$ (Wang et al. 2008; Wang et al. 2009), with the greatest elevation located in the northern-central portion of the refuge. Elevation and resulting hydrologic patterns are significant drivers of vegetation communities in the northern Everglades. The refuge was impounded by a canal and levee system on all sides during the 1950s as part of the Central and South Florida Project (Porter and Porter 2002). Surrounding canals receive water from urban and agricultural runoff during the wet season. Presently, the system relies on a combination of rainfall and managed structural inflows and outflows to control inundation and dry-down cycles (Marchant et al. 2009; Meselhe et al. 2010; Bernhardt et al. 2013).

The refuge is underlain mostly by Fort Thompson Formation, which is covered by 2 to $3 \mathrm{~m}$ of organic rich peat (Richardson et al. 1990; McCormick et al. 2011) that has been impacted by hydrologic operations. Water control structures in the northern refuge deliver mineral- and nutrient-enriched water along the refuge perimeter, which leads to loss of peat through stimulation of microbes that increase decomposition rates, particularly along areas of western perimeter marsh (McCormick et al. 2011).

Refuge marsh hydrology follows a wet and dry season pattern, with wet seasons generally beginning in May and ending in October (Bernhardt et al. 2013). Approaching the dry season, marsh water stage begins to decrease from the marsh interior (higher elevation) toward the canal with slough areas holding water longer than proximal ridge and tree island areas. Historic hydropatterns (flow and hydroperiods) and microtopographic heterogeneity within the refuge promoted development and maintenance of slough, ridge, and tree island habitats (Larsen et al. 2007 and 2010). Marsh areas directly adjacent to perimeter canals experience greater water depths and longer hydroperiods as a result of canal influence.

Nutrient-enriched runoff from agricultural and urban areas is delivered to the canals surrounding the refuge marsh through water control structures. When canal stages increase above marsh stages as a result of inflows to the canals, even at moderate rates, the enriched water can intrude into the marsh (Harwell et al. 2008; Surratt et al. 2008), resulting in long-term impacts on critical habitat components, such as vegetation and periphyton communities (McCormick et al. 2011). Canal water has been observed to penetrate into the marsh up to $3.9 \mathrm{~km}$ under moderate to high inflow ( $>20 \mathrm{~m}^{3} \mathrm{~s}^{-1}$; Surratt et al. 2008) conditions when canal stage was greater than marsh stage. Although total phosphorus $(\mathrm{P})$ is rapidly scavenged from the water column by vegetation and soil adsorption, the distance of impact from these canals can be observed in soil profiles (Reddy and Osborne 2007), periphyton composition (McCormick 2010), as well as in common surface water quality parameters (e.g., sulfate, total nitrogen, chloride, etc.; Harwell et al. 2008).

Canal water movement and distance of impact into the marsh interior can be tracked and monitored using surface water specific conductivity (Harwell et al. 2008). Harwell et al. (2008) also used surface water conductivity to further characterize the marsh into three zones of canal water influence as follows: perimeter zone $(\leq 2.5 \mathrm{~km}$ from the canal), transition zone (2.5 to $4.5 \mathrm{~km}$ from the canal), and interior zone ( $>4.5 \mathrm{~km}$ from the canal). Consequently, the distance from the canal (DFC) into the marsh serves as a crude indicator of anthropogenic impact to the refuge. As a result of these dynamics, total phosphorus concentration is a direct indicator of water quality, distance from canal $(\mathrm{km})$ is an indirect measure of hydrology and water quality (Harwell et al. 2008; Surratt et al. 2008), and days since dry (DSD; 5-year average) directly represent hydrologic conditions.

\section{Data collection}

\section{Taxa surveyed}

Seven common taxa and/or species (Bacopa caroliniana, Eleocharis elongata, Nymphoides aquaticum, Eriocaulon spp., Xyris spp., Typha spp., and Polygonum spp.) (Table 1) were selected for use in the HCAT based on CC values (Mortellaro et al. 2009) and current/historic distributions within the study site. These taxa reflect the level of habitat impact and ecological condition based on the historic and current distribution across the refuge (Gibble et al. 2013) as well as represent a range of habitats and environmental 


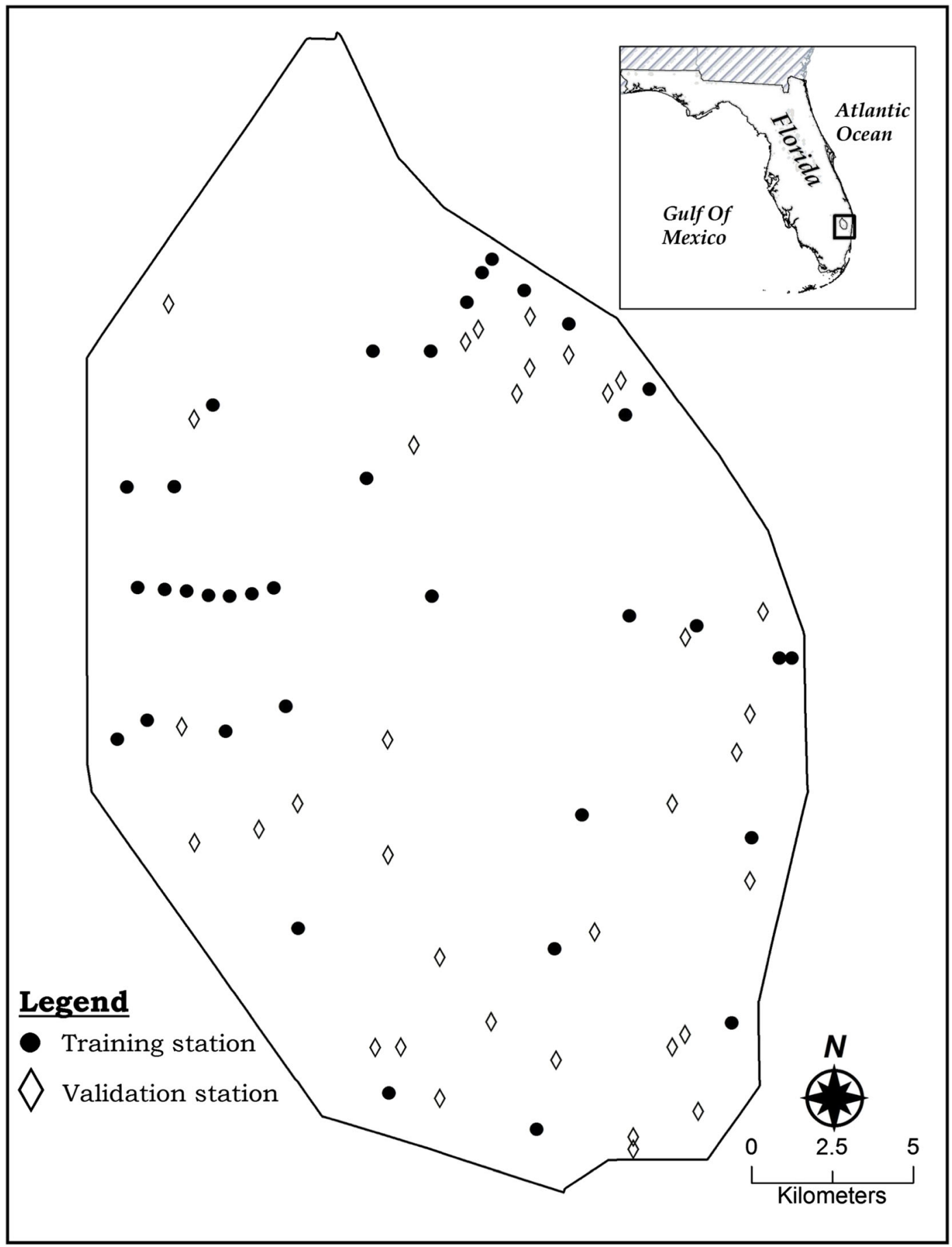

Fig. 1 Arthur R. Marshall Loxahatchee National Wildlife Refuge, Boynton Beach, FL, USA. Sampling locations indicated by solid circles (training) and open diamonds (validations)

conditions. This suite of taxa responds to changes in hydrology and nutrient levels and are useful as indicators of current conditions based on existing vegetation communities.
Within the northern Everglades, Bacopa caroliniana (lemon bacopa) is a common substrate for periphyton, the base of the Everglades food chain. This species is commonly used in aquaculture and is not generally 
sensitive to nutrient inputs. Although previous studies (Busch et al. 1998) did not find significant hydrologic relationships, B. caroliniana was found at the greatest abundances at the driest site and is known to tolerate depths up to only $1 \mathrm{~m}$ (Godfrey and Wooten 1981). Therefore, hydrological impacts are likely driving the observed distribution of $B$. caroliniana in unpublished data (Gibble et al. 2013) as a result of water levels frequently greater than $1 \mathrm{~m}$ near the adjacent perimeter canals. Although there are several species of Bacopa, the likelihood of misidentification is minimal because this species is easily identified by the lemony scent of crushed B. caroliniana leaves.

Nymphaea aquatica (banana lily) and E. elongata (slim spikerush) are both associated with undisturbed areas of deeper peat, such is found in the refuge (Davis and Ogden 1994). The distribution of E. elongata is also likely driven by primarily hydrologic factors. Miao and Zou (2012) reported significant mortality of E. elongata when water depths were increased from $20 \mathrm{~cm}$ to $60 \mathrm{~cm}$. There was also a lack of growth plasticity in response to changing water levels. Nymphaea aquatica has been characterized as decreasing in abundance in response to disturbance (Doherty et al. 2000). Further, $N$. aquatica is typically associated with low concentrations of nutrients such as phosphorus (Doherty et al. 2000). Both of these species are easily identified. Nymphaea aquatica has characteristic bumps on the underside of the large leaves that makes it distinctive from other related species. Eleocharis elongata is often

Table 1 Vegetation species, corresponding coefficients of conservatism (CC) values, and impact multiplier used as the response variables in the Habitat Characterization and Assessment Tool. Taxa with negative impact multipliers are indicators of impacted vegetation communities

\begin{tabular}{lll}
\hline Vegetation species & $\begin{array}{l}\text { Coefficient of conservatism } \\
\text { (CC) value }\end{array}$ & $\begin{array}{l}\text { Impact } \\
\text { multiplier }\end{array}$ \\
\hline $\begin{array}{c}\text { Bacopa } \\
\text { carolinensis }\end{array}$ & 8 & + \\
$\begin{array}{c}\text { Eleocharis } \\
\text { elongata }\end{array}$ & 8 & + \\
$\begin{array}{c}\text { Eriocaulon } \\
\text { compressum }\end{array}$ & 8 & + \\
$\begin{array}{c}\text { Nymphoides } \\
\text { aquaticum }\end{array}$ & 5 & + \\
$\begin{array}{l}\text { Xyris } \text { spp. } \\
\text { Polygonum spp. }\end{array}$ & 8.5 & + \\
Typha spp. & 2 & - \\
\hline
\end{tabular}

a dominant species within the study site and is distinguished from other species by small stature, growth patterns, and general appearance.

Yellow-eyed grasses (Xyris spp.) are common in the study site but are rare further south in the Everglades system (Kushlan 1990). Xyris ambigua, X. brevifolia, and $X$. smalliana are the yellow-eyed grasses that have known distributions (and vouchered specimens) within the study site. Coefficient of conservation values among Xyris species occurring within the study site range from five to eight. However, for this index, all relevant Xyris species were combined into Xyris spp. to simplify identification. The high end of the value range (8) was selected for use in the HCAT as a modified CC value for Xyris spp. This value was selected based on the published distribution of $X$. smalliana throughout the refuge, which was limited to those areas least impacted by water quality (McCormick et al. 2011) despite its moderate CC value (5), as well as the distribution observed at water quality monitoring sites across the refuge (Gibble et al. 2013). Xyris smalliana was found to lack sensitivity to exposure to common nutrients, nitrogen, potassium, or phosphorus individually, but when exposed to water chemistry similar to that found within the canal, growth rates were significantly reduced (McCormick et al. 2011). The other two Xyris species that may occur within the refuge ( $X$. ambigua and $X$. brevifolia) both have high CC values ( 8 and 7 , respectively). Use of the modified CC value for Xyris spp. is therefore appropriate for this tool when used in the northern Everglades. Like X. smalliana, $E$. compressum was only found at sites in the refuge that were distant from the canal in a previous study (McCormick et al. 2011). Eriocaulon species with vouchered specimens in Florida (E. compressum and $E$. decangulare) are easily identified by a white flower spike when blooming. Annual surveys are targeted for completion between May and October when this often submerged species is most visible. When not blooming, this species can still be easily identified at close proximity by its characteristic cellular leaf structure. Additionally, all species found in Florida have CC values of eight or nine.

Typha spp. (cattail) is a well-established indicator of stress (both nutrient enrichment and hydrology) within numerous ecosystems, including wetlands and lakes of the Everglades (Davis and Ogden 1994). Various species of both Typha and Polygonum (smartweed) were also found to be positively correlated with stress in the 
habitats of the Great Lakes (Johnston et al. 2008; Doherty et al. 2000; Lane et al. 2003). Typha spp. and Polygonum spp. were present across the study area with a high frequency in high impact areas in available datasets (Rutchey et al. 2006; Gibble et al. 2013). Like Xyris, Polygonum and Typha were only required to be identified to genus for the HCAT in order to simplify identification. This was considered an acceptable modification for Typha, because both species likely to be found in the northern Everglades have the same low CC value of two. Of the Polygonum species present in the study area, $P$. setaceum has a relatively high $\mathrm{CC}$ value of seven and may only infrequently occur within the study site. Polygonum hydropiperoides, with a $\mathrm{CC}$ value of three, is much more common throughout the southeast coastal areas, and Polygonum spp. is typically found in impacted areas of the study site as determined by unpublished data collected during routine water quality monitoring (Gibble et al. 2013). Therefore, Polygonum spp. was assigned an overall value of 3.5 due to its limited distribution in the refuge and observed preference for impacted sites within the study site.

Published CC values for native Florida flora taxa range from zero to ten. Index values near zero indicate taxa that are commonly found in ruderal conditions. Taxa assigned higher index values are more closely associated with natural, unimpacted conditions (Mortellaro et al. 2009). Species commonly observed in the refuge have $\mathrm{CC}$ values ranging from two to eight. Taxa selected as indicators are consistent with distributions relative to habitat quality observed in the refuge, meaning that taxa with $\mathrm{CC}$ values below five are generally located in areas of nutrient enrichment (impacted) in the perimeter zone $(<2.5 \mathrm{~km}$ from the canal), while taxa with values of five or greater are found further away from the canal water influence in the transition zone ( 2.5 to $4.5 \mathrm{~km}$ from the canal) and interior zone $(>4.5 \mathrm{~km}$ from the canal). Two of the seven taxa (Polygonum spp. and Typha spp.) reflect impacted conditions while the remaining taxa reflect more natural conditions.

These seven taxa were incorporated into the surface water quality sampling program for the South Florida Management District (SFWMD), and observations at fixed monitoring stations have occurred monthly since 2007. Surveys were conducted at a series of fixed longterm monitoring stations in the wet and dry seasons of 2009 and 2011 (model training dataset) and at randomly selected validation stations in the dry season of 2013 (Fig. 1). The validation sample design was stratified across three marsh water quality zones taking into account variance of the index values determined from the long-term stations and a 90\% confidence interval. All stations, long-term and validation, were accessed by float helicopter or airboat with efforts to reduce station disturbance from vehicular influence during sample collection. For the long-term fixed stations, select taxa were surveyed with $1 \mathrm{~m}^{2}$ quadrats to determine relative percent cover and taxa presence-absence at 10 plots spaced at 5-m intervals along one 50-m transect per site within $100 \mathrm{~m}$ of station center.

Validation stations were surveyed using a rapid assessment protocol developed by an interagency team (US Fish and Wildlife Service, Everglades National Park, and South Florida Water Management District). This protocol requires the sampler to walk a distance of $20 \mathrm{~m}$ from the access vehicle to the sampling location. The sampler records only the presence of any of the seven indicator taxa observed within $1 \mathrm{~m}$ on either side of the 20-m path while walking to a randomly selected water sampling location, and it also records any taxa present within $25 \mathrm{~m}$ ( $360^{\circ}$ field of view) of the sampling location. No other parameters, such as percent cover, are recorded using this rapid assessment methodology.

\section{Abiotic factors influencing vegetation community composition}

Several major abiotic factors that influence vegetation community composition were assessed to understand their influence on refuge-specific vegetation community composition. Abiotic factors assessed at each station include the following: hydrology (days since dry and 365-day average depth), topography, spatial location, and surface water quality (explained in more detail below). Water depths and hydroperiod have been shown to be directly related to vegetation community composition including in the refuge marsh, although individual species response is varied (Newman et al. 1996; King et al. 2004). Distance from canal influences the water quality found at each station (Harwell et al. 2008; Surratt et al. 2008), and water quality has been shown to influence vegetation community composition (Newman et al. 1996; Hagerthey et al. 2008; McCormick 2010). Adjacent canals also strongly influence water levels around the perimeter of the refuge, resulting in greater depths and longer hydroperiods (McCormick et al. 2011). In addition to water quality, spatial patterns of refuge vegetation are also correlated with hydrologic 
gradients that are driven largely by an elevation gradient that extends north to south (Richardson et al. 1990).

\section{Hydrology}

Days since dry (DSD; 5-year average) and 365-day average depth were determined from water depth, which was determined daily at individual stations as the difference between the nearest stage gage data available through the SFWMD DBHYDRO database (South Florida Water Management District 2018) value and the station-specific elevation. Days since dry represents the number of consecutive days since a station experienced surface water depths below $0 \mathrm{~cm}$. The total number of days was averaged over 5 or 10 years for each station. The 365-day average depth was calculated as a 365-day rolling average surface water depth at each station applied on the day of vegetation sample collection.

\section{Water quality}

Surface water samples were collected monthly from each long-term water quality monitoring station and were used for the model training set. Water samples were collected only once during the vegetation sampling event at randomly selected validation stations. Samples were collected in clean Nalgene ${ }^{\circledR}$ bottles when clear water depths were greater than $10 \mathrm{~cm}$ (measured at the station during sample collection) to avoid entraining sediment or plant-associated particles, often enriched in phosphorus. Between $250 \mathrm{~mL}$ and $4 \mathrm{~L}$ of surface water was collected from each station, depending on conditions, and transported to either SFWMD or ALS Analytical (Columbia, MD) for chemical analyses. Both laboratories are certified by the National Environmental Laboratory Accreditation Conference and have participated in the "Everglades Round Robin" cross-laboratory comparisons for low-level phosphorus analyses. Split samples have been tested by both laboratories to ensure comparability of chemical analyses between laboratories. The percent relative difference between the laboratories for phosphorus remained below 10\%. Samples sent to ALS Analytical were preserved in the field using sulfuric or hydrochloric acid, stored on ice, transported to the on-site laboratory for any further processing (e.g., filtering, packing), then shipped on ice overnight to ALS Analytical for chemical analyses. Samples sent to SFWMD's laboratory were stored on ice and transported back to the SFWMD laboratory for preservation and filtration before on-site analysis. All samples were processed within a standard 4-h holding time. Portable data loggers (Hydrolab, Mini Sonde 4a or 5) were also used according to established protocols (South Florida Water Management District 2010) during sampling events to measure specific conductivity levels at each station.

Statistical analyses

\section{Vegetation community}

Similarity of vegetation communities at surveyed sites was assessed using the inverse of a Jaccard similarity index (JSI) (Gardner 2014) calculated based on year, water quality zone, and season. The inverse JSI was calculated as the total number of indicator species present (i.e., total richness) minus the total common taxa divided by the total richness and compared among years, zones, and seasons. Inverse JSI values range from zero (no taxa in common) to one (perfect alignment of taxa). A percent of taxa commonality measure was determined by subtracting the index value from one and multiplying by 100 .

\section{Water quality}

Mann-Whitney U was used to test for differences in total phosphorus and conductivity among years, seasons, and zones (Snedecor and Cochran 1989; Zar 1999), similar to the approach used by Harwell et al. (2008).

\section{Habitat characterization and assessment tool (HCAT) development}

The HCAT includes rapid assessment of habitat condition using a vegetation survey method that focuses on presence/absence of key indicator taxa, greatly reducing the time required to complete surveys and minimizing misidentification of taxa. Modified FQI values calculated using rapid assessment data were then modeled to determine the driving factors for observed habitat condition.

Modified FQI (response variable) A modified FQI was developed based on presence-absence of select taxa at long-term water quality monitoring stations throughout the refuge. Coefficients of Conservatism values for 
Polygonum spp. and Typha spp. were transformed by multiplying them by an impact multiplier of negative one (Table 1) in order to increase the range of responses and tool sensitivity. Alternatively, for taxa with a higher affinity to natural areas, $\mathrm{CC}$ values were multiplied by an impact multiplier of positive one. The modified FQI equaled the sum of the transformed $\mathrm{CC}$ values for each station. Across the sampled stations, the modified FQI calculation resulted in a range of values from -1 to 37 , where -1 reflects monotypic stands of taxa indicative of impacted conditions and 37 reflects stations indicative of the most natural conditions within the refuge.

HCAT model The HCAT models the modified FQI using multiple linear regression in the $\mathrm{R}$ statistical computing environment (R Core Team 2014). Conceptually, the HCAT model aims to account for variability in the response variable (modified FQI) with respect to regularly monitored drivers. The conceptual model for this relationship takes the form:

Response $($ modified FQI) $=$ Hydrologic Effect + Spatial Effect + Water Chemistry Effect

Average annual water depths and days since dry averaged over 5 or 10 years represented hydrologic effects. The shortest distance from the closest canal to each station represented spatial effects and water chemistry effects represented total phosphorus and conductivity.

The model was calibrated by testing the modified FQI as the response variable against a suite of explanatory variables. Reduction of explanatory variables was performed using Akaike information criterion (AIC) in the $\mathrm{R}$ package. Residuals of each reduced model were tested for normality using Anderson-Darling, Lilliefors (Kolmogorov-Smirnov), Pearson chi-square, and Shapiro-Wilk tests for normality in R using the "nortest" package (Gross and Ligges 2012). Residuals from the model were normally distributed.

The multivariate regression model takes the form:

$$
\begin{aligned}
\text { Modeled Modified FQI }= & \mathrm{m}+\mathrm{b}_{1} \mathrm{DSD}+\mathrm{b}_{2} \mathrm{DFC} \\
& +\mathrm{b}_{3} \ln (\mathrm{TP})+\mathrm{b}_{4} \text { Cond }
\end{aligned}
$$

where

$$
\begin{aligned}
& m=\text { intercept } \\
& b_{x}=\text { slope coefficients } \\
& \text { DSD = days since dry (5-year average) }
\end{aligned}
$$

$$
\begin{aligned}
& \mathrm{DFC}=\text { distance from canal }(\mathrm{km}) \\
& \mathrm{TP}=\text { total phosphorus }\left(\mu \mathrm{g} \mathrm{L} \mathrm{L}^{-1}\right) \\
& \text { Cond = specific conductivity }\left(\mu \mathrm{S} \mathrm{cm}{ }^{-1}\right)
\end{aligned}
$$

\section{Verification of model of modified FQI}

The validity of the model was verified using several approaches. First, an assessment of the model concepts was performed. Professional judgment and a conceptual model were used to generate (Fig. 2) as a modified subset of the larger ridge and slough conceptual model presented by Ogden (2005). Solutes in agricultural and urban runoff greatly influences the composition of surface water delivered to the refuge and acts as a stressor that degrades habitat quality. Further, precipitation and managed water flows drive refuge hydroperiods and water depth, which also influence habitat quality as indicated by vegetation community assemblages on the refuge. Understanding these dynamics informed the stressors/drivers selected as input into the HCAT numerical model.

Following verification using conceptual models, a statistical verification approach was applied to the training dataset. Means of the observed response variable from the training dataset were statistically compared with model projections of the vegetation response variable based on the training dataset using the MannWhitney U test (Snedecor and Cochran 1989; Zar 1999).

The resulting model was applied to the validation dataset to verify the modeling approach. This approach simply compared the means for the modeled validation dataset and the observed response variables using the Mann-Whitney $U$ test to assess model performance in locations outside the long-term sampling locations.

\section{HCAT spatial interpretation}

The range of values that indicated low, moderate, and high levels of impact were determined by assessing the spatial distribution of the modified FQI scores as related to DFC using change-point analysis. Change-point analysis, using Taylor Enterprise software-Change-Point Analyzer (Taylor 2001), combines cumulative sum charts and bootstrapping in an iterative manner to detect changes in the time series, which indicates thresholds of impact that lead to observable change. 
Fig. 2 Conceptual model of drivers (rectangles), stressors (rounded squares), ecological effects (diamonds), and ecological attributes (hexagon) of concern

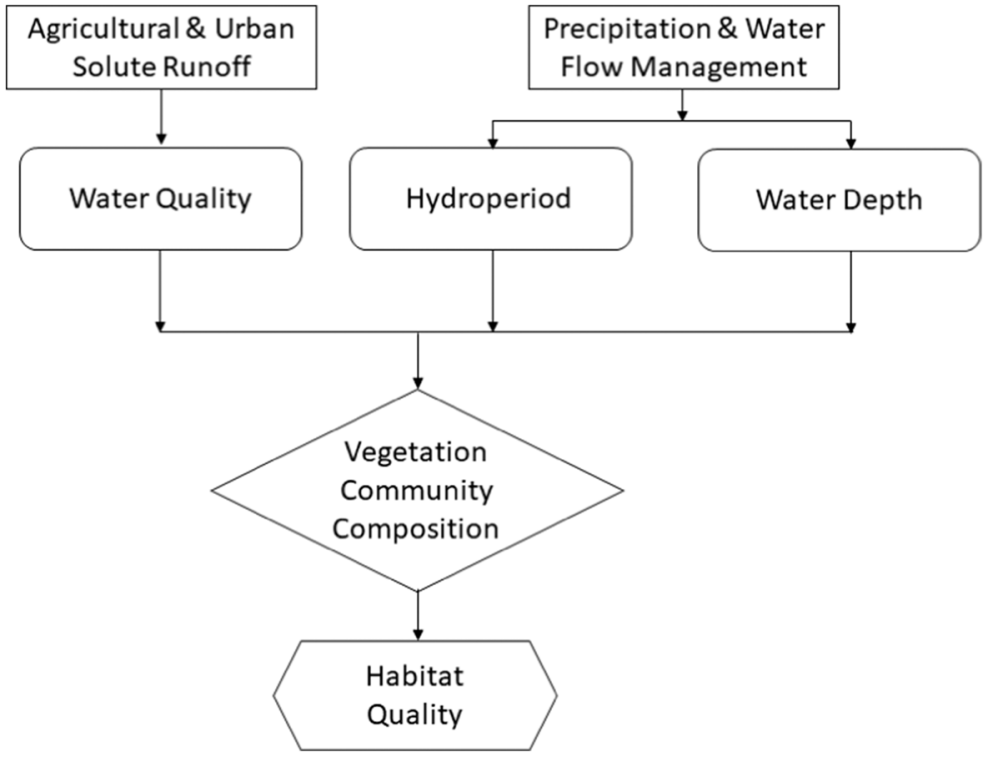

\section{Results and discussion}

Abiotic factors affecting vegetation community composition

Comparisons among years, seasons, and zones indicate differences in mean total phosphorus, mean specific conductivity levels, and/or mean days since dry (5-year average). Mean total phosphorus concentrations in 2009 (7.2 $\pm 0.4 \mu \mathrm{g} \mathrm{L}^{-1}$; mean \pm standard error) were significantly higher $(p<0.01$; Mann-Whitney $\mathrm{U})$ than in 2011 $\left(6.2 \pm 0.6 \mu \mathrm{g} \mathrm{L}^{-1}\right)$ and similar to concentrations observed in $2013\left(7.2 \pm 0.8 \mu \mathrm{g} \mathrm{L}^{-1}\right)$, while 2011 concentrations were significantly lower $(p<0.05$; MannWhitney U) than in 2013 (Table 2). Mean specific conductivity levels across Zones in 2009 (132 \pm $11 \mu \mathrm{S} \mathrm{cm}^{-1}$ ) were similar to levels observed in 2011 $\left(131 \pm 12 \mu \mathrm{S} \mathrm{cm}^{-1}\right)$, while 2009 and 2011 levels were significantly lower ( $p<0.05$; Mann-Whitney $\mathrm{U})$ than in $2013\left(200 \pm 26 \mu \mathrm{S} \mathrm{cm}^{-1}\right)$ (Table 2). Average days since dry (5-year average) was similar between 2009 (1272 \pm 111 days) and 2011 (1310 \pm 112 days), but both years had significantly shorter durations $(p<0.05$; Mann Whitney U) than during $2013(2504 \pm 205$ days $)$ (Table 2).

Across all years, mean total phosphorus concentrations in the perimeter zone $\left(7.8 \pm 0.4 \mu \mathrm{g} \mathrm{L}^{-1}\right)$ were significantly higher $(p<0.01$; Mann-Whitney $\mathrm{U})$ than in the transition $\left(5.8 \pm 0.7 \mu \mathrm{g} \mathrm{L}^{-1}\right)$ and interior $(5.7 \pm$ $0.5 \mu \mathrm{g} \mathrm{L}^{-1}$ ) zones, while there was no significant difference between the transition zone and interior zone concentrations (Table 2). Mean specific conductivity in the perimeter zone $\left(205 \pm 14 \mu \mathrm{S} \mathrm{cm}^{-1}\right)$ was significantly higher $(p<0.01$; Mann Whitney $\mathrm{U})$ than in the transition zone $\left(98 \pm 9 \mu \mathrm{S} \mathrm{cm}^{-1}\right)$ and interior zone $(80 \pm$ $6 \mu \mathrm{S} \mathrm{cm}^{-1}$ ), while there was no significant difference between the transition zone and interior zone levels. Perimeter zones were wetter than the transition and interior zones as indicated by days since dry over 5 years in the perimeter zone $(1925 \pm 115$ days $)$ being significantly higher $(p<0.01$; Mann-Whitney $\mathrm{U})$ than in the transition $(1287 \pm 148$ days $)$ and interior $(1104 \pm$ 151 days) zones, while transition and interior zones were not statistically different (Table 2).

Seasonal comparisons were also conducted, and overall wet season mean $( \pm \mathrm{SE})$ total phosphorus concentrations $\left(7.6 \pm 0.5 \mu \mathrm{g} \mathrm{L}^{-1}\right)$ were significantly higher $(p<0.01)$ than dry season concentrations $(5.5 \pm$ $\left.0.4 \mu \mathrm{g} \mathrm{L}^{-1}\right)$. Mean $( \pm \mathrm{SE})$ conductivity levels were similar between wet $\left(131 \pm 11 \mu \mathrm{S} \mathrm{cm}^{-1}\right)$ and dry $(127$ $\pm 11 \mu \mathrm{S} \mathrm{cm}^{-1}$ ) seasons. Mean ( \pm SE) DSD (5 year) were also similar between wet $(1297 \pm 105)$ and dry seasons (1286 \pm 110$)$.

Vegetation community similarity

Percentages of shared taxa and spatial distribution of taxa across the refuge were compared by year, season, and zone (Table 3a-c). The percentage of taxa shared throughout the refuge among years ranged from 42 to 
Table 2 Index value means and standard errors (parentheses) of model parameters (left column) organized by water quality zones and years. Letters $(a, b, c)$ reflect significant $(p<0.01$; Mann-
Whitney U test) differences among zones. Numbers situated next to letters reflect significant (Mann-Whitney U test) differences among years

\begin{tabular}{|c|c|c|c|c|c|}
\hline Parameter & Zone & 2009 & 2011 & 2013 & All years \\
\hline \multirow[t]{4}{*}{$N$} & Perimeter & 28 & 36 & 16 & 80 \\
\hline & Transition & 17 & 18 & 13 & 48 \\
\hline & Interior & 18 & 18 & 6 & 42 \\
\hline & All zones & 63 & 72 & 35 & 170 \\
\hline \multirow[t]{4}{*}{ Modified index value } & Perimeter & $7.9(0.9)^{\mathrm{a} 1}$ & $7.5(0.9)^{\mathrm{a} 1}$ & $9.1(2.0)^{\mathrm{a} 1}$ & $8.0(5.7)^{\mathrm{a}}$ \\
\hline & Transition & $15.5(2.1)^{\mathrm{b} 1}$ & $15.7(2.0)^{\mathrm{b} 1}$ & $18(2.4)^{\mathrm{a} 2}$ & $16.3(8.4)^{\mathrm{b}}$ \\
\hline & Interior & $21.3(1.9)^{\mathrm{a} 1}$ & $21.6(1.6)^{\mathrm{c} 2}$ & $26.3(4.5)^{\mathrm{a} 2}$ & $22.1(7.9)^{\mathrm{c}}$ \\
\hline & All zones & $13.8(9.0)^{1}$ & $13.1(8.7)^{2}$ & $15.3(10.7)^{1}$ & $13.8(0.7)$ \\
\hline \multirow[t]{4}{*}{ Total phosphorus $\left(\mu \mathrm{g} \mathrm{L}^{-1}\right)$} & Perimeter & $8.5(0.6)^{\mathrm{a} 1}$ & $7.5(0.8)^{\mathrm{a} 1}$ & $7.4(0.7)^{\mathrm{a} 1}$ & $7.8(0.4)^{\mathrm{a}}$ \\
\hline & Transition & $5.1(0.6)^{\mathrm{b} 1}$ & $4.9(0.9)^{\mathrm{b} 1}$ & $7.9(1.9)^{\mathrm{a} 2}$ & $5.8(0.7)^{\mathrm{b}}$ \\
\hline & Interior & $7.2(0.6)^{\mathrm{a} 1}$ & $4.3(1.0)^{\mathrm{b} 2}$ & $5.4(0.4)^{\mathrm{a} 2}$ & $5.7(0.5)^{\mathrm{b}}$ \\
\hline & All zones & $7.2(0.4)^{1}$ & $6.2(0.6)^{2}$ & $7.2(0.8)^{1}$ & $6.7(0.3)$ \\
\hline \multirow[t]{4}{*}{ Specific conductivity $\left(\mu \mathrm{S} \mathrm{cm}^{-1}\right)$} & Perimeter & $184(20)^{\mathrm{a} 1}$ & $184(15)^{\mathrm{a} 1}$ & $287(44)^{\mathrm{a} 2}$ & $205(14)^{\mathrm{a}}$ \\
\hline & Transition & $85(12)^{\mathrm{b} 1}$ & $76(8)^{\mathrm{b} 1}$ & $145(22)^{\mathrm{b} 2}$ & $98(9)^{\mathrm{b}}$ \\
\hline & Interior & $95(6)^{\mathrm{c} 1}$ & $63(11)^{\mathrm{b} 2}$ & $87(7)^{\mathrm{c} 1}$ & $80(6)^{b}$ \\
\hline & All zones & $132(11)^{1}$ & $131(12)^{1}$ & $200(26)^{2}$ & $144(8)$ \\
\hline \multirow[t]{4}{*}{ Days since dry (5-year average) } & Perimeter & $1650(152)^{\mathrm{a} 1}$ & $1673(133)^{\mathrm{a} 1}$ & $2972(299)^{\mathrm{a} 1}$ & $1925(115)^{\mathrm{a}}$ \\
\hline & Transition & $1045(221)^{\mathrm{b} 1}$ & $993(214)^{\mathrm{b} 1}$ & $2011(283)^{\mathrm{a} 2}$ & $1287(148)^{b}$ \\
\hline & Interior & $901(180)^{\mathrm{b} 1}$ & $901(180)^{\mathrm{b} 1}$ & $2324(549)^{\mathrm{a} 2}$ & $1104(151)^{b}$ \\
\hline & All zones & $1272(111)^{1}$ & $1310(112)^{1}$ & $2504(205)^{2}$ & $1542(82)$ \\
\hline
\end{tabular}

$45 \%$. Thirty-six percent of the taxa observed during the wet season were observed during the dry season. The seasonal comparison excludes 2013, when only dry season samples were collected. Among zones, the transition and interior zones (29\% had the highest percentage of vegetation taxa in common with and the perimeter and interior zones $(21 \%)$ had the lowest community similarity.

Distribution differences in the spatial distribution of taxa were observed within seasons (Fig. 3a-c). During the wet season (Fig. 3a), Bacopa caroliniana distribution in the marsh ranged from about $0.5 \mathrm{~km}$ from the canal to approximately $8.2 \mathrm{~km}$ in 2009 but receded to about a maximum distance of $4.2 \mathrm{~km}$ from the canal in 2009. Wet season Nymphoides aquatica spanned from between 3 and $5 \mathrm{~km}$ to over $9 \mathrm{~km}$ into the marsh from the canal. Polygonum spp. were only observed in 2009 during the wet season at about $1 \mathrm{~km}$ into the marsh from the canal.

Dry season spatial variability was observed among the three sampling years (Fig. 3b-c). Bacopa caroliniana spanned between 1.3 and $8.2 \mathrm{~km}$ into the marsh from the canal in 2009 and had similar spatial cover in 2011 except with the distribution extended to about $0.8 \mathrm{~km}$ from the canal at this time point (Fig. 3b). However, in 2013 (Fig. 3c), Bacopa caroliniana was not observed until about $1.7 \mathrm{~km}$ into the marsh from the canal, although spatial coverage in the marsh was similar to 2009 and 2011. Nymphoides aquatica was observed during dry season sampling events between 1.5 and $9.7 \mathrm{~km}$ into the marsh from the canal during the dry season in 2009 and 2011. In 2013, N. aquatica was observed between 2.5 and the furthest sampling site from the canal (8.4), similar to observations made in the 2009 and 2011 wet season. Dry season observation of Xyris spp. in 2009 and 2011 covered from 4 to $9.7 \mathrm{~km}$ into the marsh, and the range extended from 1.8 to the maximum sampling distance of $8.4 \mathrm{~km}$ in 2013. Typha spp. observation extended from the marsh edge to about $1.8 \mathrm{~km}$ into the marsh in the dry seasons of 2009 and 2011 but extended to $2.7 \mathrm{~km}$ in 2013 .

Community similarity index values were largely consistent among years and between seasons, although there was slightly lower similarity between seasons, 
Table 3 Percent of taxa shared among (a) years, (b) season, and (c) zones based on Jaccard similarity index

\begin{tabular}{ll}
\hline (a) Year & \% Similarity \\
\hline 2009 to 2011 & 45 \\
2009 to 2013 & 45 \\
2011 to 2013 & 42 \\
(b) Season & \\
Dry to wet & 36 \\
(c) Zones & \\
Perimeter to transition & 23 \\
Perimeter to interior & 21 \\
Transition to interior & 29 \\
\hline
\end{tabular}

possibly because of seasonal patterns of blooming and visibility. The HCAT was further validated by similar trends in community similarity and modified FQI values, in which the moderate and low impact transition and interior zones had the most taxa in common, while the highest and least impacted perimeter and interior zones had the fewest taxa in common. This finding was expected, as the highest impact sites were primarily monocultures of dense Typha with limited species, such as Polygonum, also present at much lower densities. Presence frequency of taxa serving as indicators of quality habitat rise as distance from canal increases. Therefore, the highest community similarity would be expected between the moderate and low impact because of the extremely low diversity of the high impact zone, as observed.

\section{HCAT}

\section{Model calibration}

Following vegetation community driver reduction, calibration of the model resulted in significant correlations between the response variable (i.e., modified FQI) training dataset and the distance from canal (DFC), days since dry (DSD) averaged over 5 years, and the natural log of total phosphorus. The average days since dry over 10 years, 365-day average water depth, and average conductivity were eliminated during the AIC analysis. The resulting multivariate model was:
Modified Floristic Quality Index

$$
=m+b_{1} D S D+b_{2} D F C+b_{3} \ln (T P)
$$

Modified Floristic Quality Index

$$
\begin{aligned}
& =17.65542-0.0040820 * D S D \\
& +1.8991772 * D F C-2.9182566 * \ln (T P)
\end{aligned}
$$

The model explained $67 \%$ of the variance in the training dataset with a residual standard error of 5.02. Further, the model was significant at $p<0.001$.

\section{Model validation}

Mean of the observed modified FQI (13.4) for the complete training dataset was consistent with the projected modified FQI (13.2) based on results of the Mann-Whitney U test ( $p$ value). Applying the model to the validation dataset and regressing the observed and projected response variable values resulted in a $\mathrm{R}^{2}$ of 0.56 with a residual standard error of 3.73 and a $p$ value less than 0.001 . Further, there was no significant difference between the observed mean of the validation dataset and predicted values for the modified FQI.

\section{Modified floristic quality index (response variable)}

The lowest modified FQI scores (reflecting high impact conditions) were found up to $1.36 \mathrm{~km}$ from the perimeter canal, mid-range modified FQI values were generally located from $1.36 \mathrm{~km}$ to $3.91 \mathrm{~km}$ from the canal, and the highest index values, indicating the least impacted vegetation communities, were found at locations greater than $3.91 \mathrm{~km}$ from the perimeter canal (Figs. 4 and 5).

Mean modified FQI values were similar between $2009(13.8 \pm 9.0)$ and $2013(15.3 \pm 10.7)$, but both years had higher values than in 2011 (13.1 \pm 8.7 ; Table 2$)$. Wet $(12.6 \pm 8.5)$ and dry $(14.7 \pm 9.7)$ season index values were also similar, regardless of year. By zones, across all years, index values significantly increased $(p<0.01$; Mann-Whitney $U)$ from the perimeter zone $(8.0 \pm 5.7)$ to the interior $(22.1 \pm 7.9)$ zones 


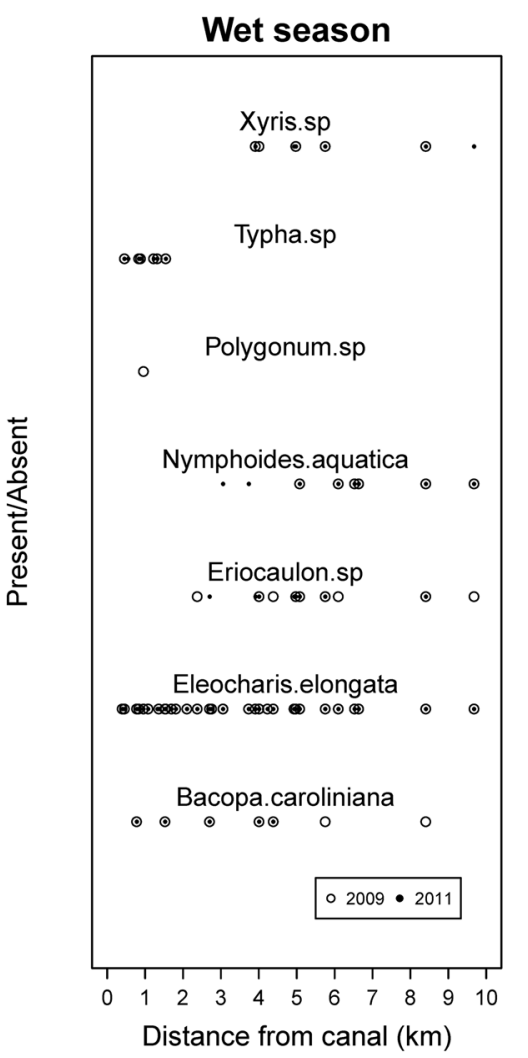

Fig. 3 Taxa presence/absence data by distance from canal for 2009 and 2011 wet season survey (left panel), 2009 and 2011 dry season survey (center panel), and 2013 dry season validation survey (right panel). Taxa indicated with "sp." include modified

\section{HCAT levels of impact target}

Results from the change-point analysis on the modified FQI scores sorted as distance from canal resulted in two change-points (Fig. 4). The first change-point $(99 \%$ confidence) was situated at $1.36 \mathrm{~km}$ into the marsh from the canal and reflected a change from an average modified FQI score of 6 prior to $1.36 \mathrm{~km}$ to 11 at distances from the canal greater than $1.36 \mathrm{~km}$ into the marsh. The second change-point ( $100 \%$ confidence) was situated at $3.91 \mathrm{~km}$ into the marsh from the canal and reflected a change from an average response variable score of 11 to 21 at distances greater than $3.91 \mathrm{~km}$ into the marsh. Thus, based on characterized water zones, a value of 6 or below reflected high impact, between 6 and 21 represented moderate impact, and values 21 or higher were areas reflective of low impact (Fig. 5).

The HCAT provides a rapid 1st-order screening tool to assess habitat and inform management and restoration decisions in the northern Everglades. This tool employs
Dry season

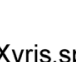

$\underset{\oplus}{\text { Xyris.sp }}$

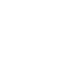

pha.sp

Polygonum.sp

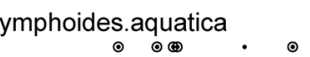

Eriocaulon.sp Eriocaulon.sp

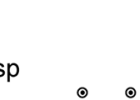

Eleocharis.elongata

Bacopa.caroliniana

\section{$\circ 2009 \cdot 2011$}

$\begin{array}{lllllllll}2 & 3 & 4 & 5 & 6 & 7 & 8 & 9 & 10\end{array}$

tance from canal $(\mathrm{km})$
Dry season - validation

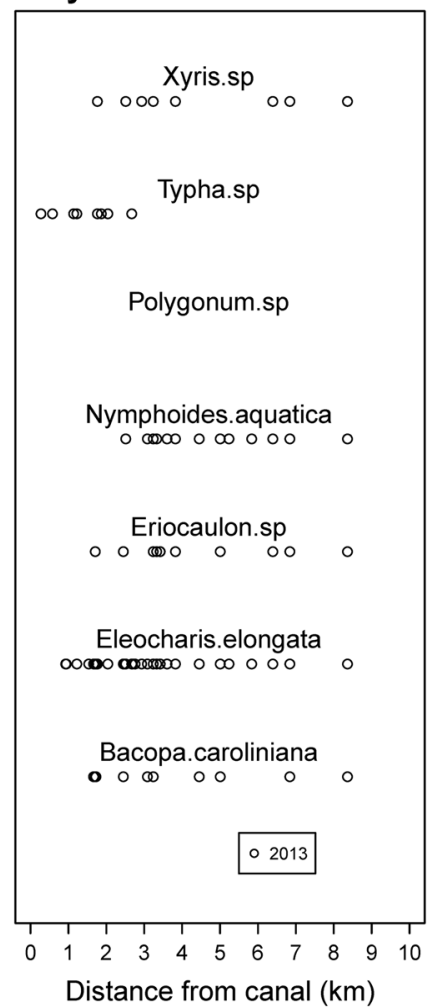

$\mathrm{CC}$ values due to multiple potential species potentially being present, but all indicate similar levels of impact in this system. See text for more information

simplified vegetation surveys and a modified FQI for rapidly assessing the level of impact to vegetation communities resulting of degraded environmental conditions, such as water quality and hydrology, which ultimately can reduce the capacity of an area to maintain natural function and support sensitive wildlife species. The HCAT also has predictive capabilities to help better understand the potential impacts of proposed projects and can also be integrated into management decisions through the development of performance measures and specific targets or thresholds.

Expert opinion, current and historic vegetation distribution, and published $\mathrm{CC}$ values were used to select the species included in the index. Richness and abundance factors are commonly used in typical FQIs; however, these metrics are highly influenced by sampling effort and sampling area potentially leading to misleading or counterintuitive results (Andreas et al. 2004; Miller and Wardrop 2006). Rooney and Rogers (2002) ultimately determined that FQIs without a species richness 


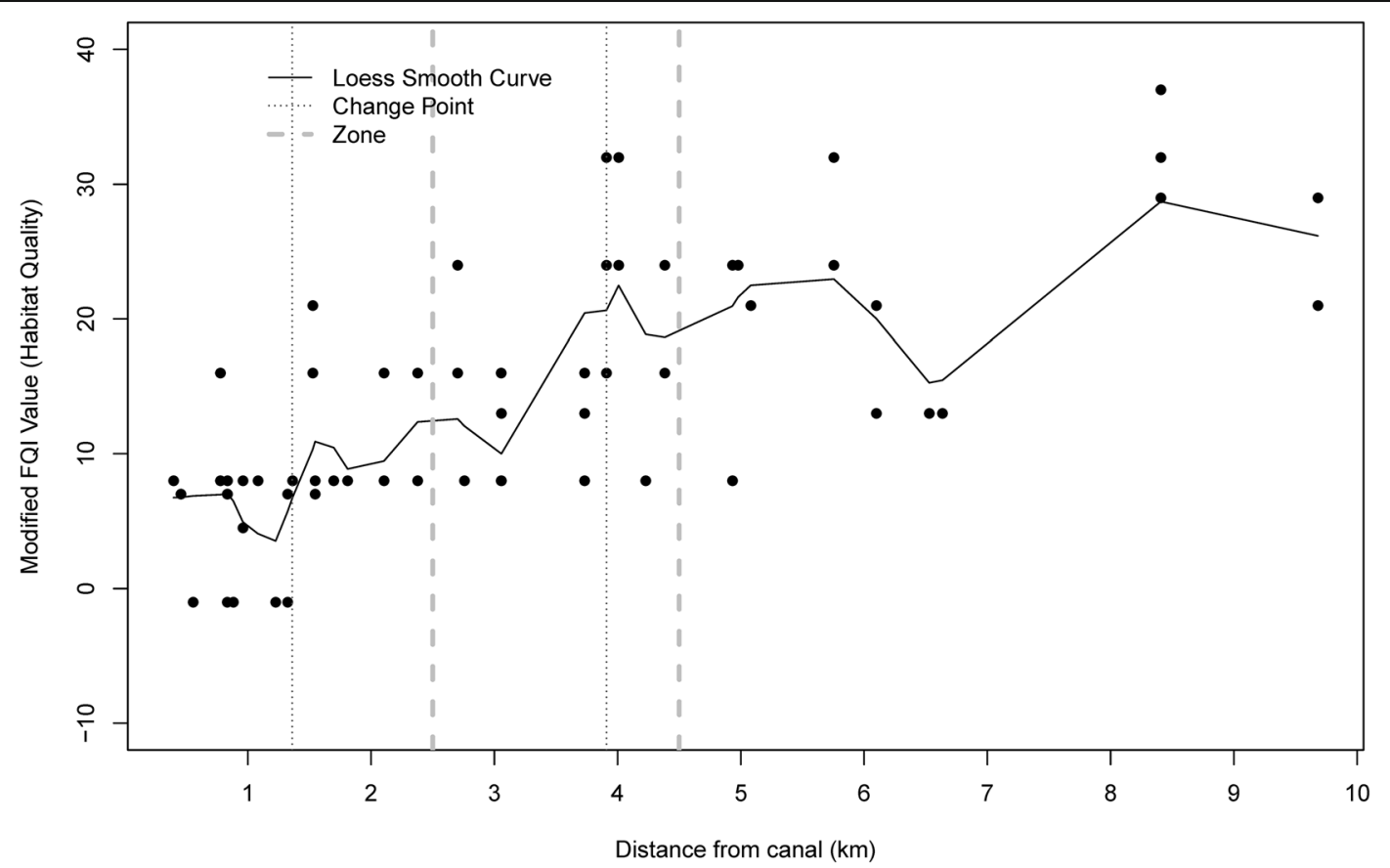

Fig. 4 Change-points of the modified FQI scores (as Loess smooth curve) based on distance from canal into the marsh. Red vertical lines represent change-points, while the solid black line

multiplier was more appropriate for comparing similar habitat types. Therefore, neither richness nor abundance were included in the HCAT in order to simplify data collection and avoid producing biased or unreliable results.

The modified FQI response variable was modeled with readily available environmental data, which is a represents modified FQI scores. Dashed vertical lines represent boundaries of water quality zones described in Harwell et al. (2008)

novel approach for applying FQAs (FQIs) to predict impacts of planned projects or management operations and inform management decisions. The final model included hydrology (days since dry; 5 year average) and water quality (distance from canal and TP) parameters, which aligned with hydrologic trends and water quality zones described by Harwell et al. (2008) (Fig. 4).
Fig. 5 Boxplots, including range and mean and standard deviations, of modified FQI values based on change-point analysis. High impact represent modified FQI scores from the canal into $1.36 \mathrm{~km}$ into the marsh; moderate impact represent modified FQI scores from $1.36 \mathrm{~km}$ into the marsh up to $3.91 \mathrm{~km}$ into the marsh; and low impacts represent modified FQI scores $3.91 \mathrm{~km}$ into the marsh and greater

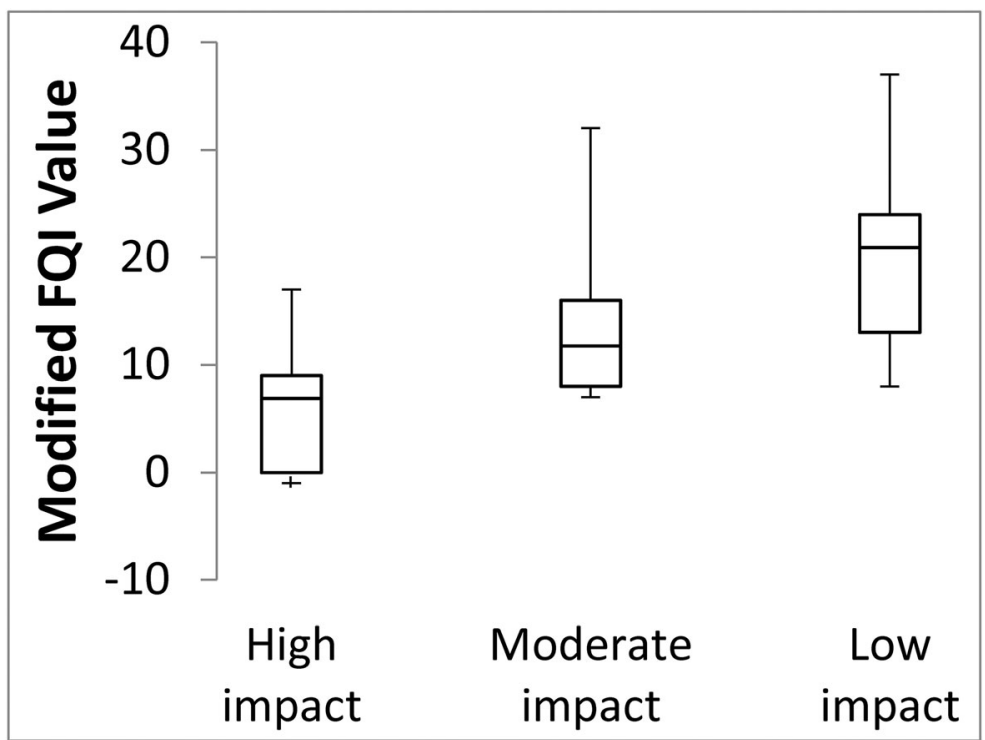


Although community similarity did not differ between years, there were differences between zones, where the transition and interior zones were more similar than perimeter and transition or Interior zones (Table 3). This result was expected, as the perimeter zone is highly impacted and the vegetation community is largely dominated by taxa indicative of impact (Typha and Polygonum). The strong similarity and correlation between the modified FQI distribution and environmental drivers (hydrology and water quality) as indicated in Harwell et al. (2008) increase confidence in the modified FQI as a tool for assessing habitat condition and indicate that the index is sensitive enough to distinguish between low, moderate, and high levels of impact based on sitespecific vegetation communities.

The results of this study indicate the HCAT is sensitive enough to detect significant changes in plant communities and habitat condition, including the introduction of negative indicators within a site, but it should be noted that this method was not designed to detect early loss of rare species. Negative transformation of the $\mathrm{CC}$ values for indicators of impact (Typha spp. and Polygonum spp.), which are typically absent from non-impacted sites (Fig. 3), increased the sensitivity of the HCAT. This transformation increased the range of the response variable and increased analysis sensitivity, which allows the observation of stepwise degradation using the expansion of negative indicators (e.g., cattail) as markers of degradation. If impact at a site continues, expansion of negative indicators is typically followed by the loss of high-quality habitat indicators, as occurs in typical habitat degradation pathways.

The HCAT provides a framework for using select plant taxa to characterize the level of impact based on the distribution of included taxa. The distribution of target species in the current study (Fig. 3) support the use of Typha spp. and Polygonum spp. as indicators of impact (negative CC values), as they were only present near perimeter canals. Distribution patterns also indicate that Xyris spp., N. aquatica, and Eriocaulon spp. are the most sensitive indicators of non-impacted sites as these species were present at sites greater than $1.5 \mathrm{~km}$ from the canal and absent from sites closest to the canal. Eleocharis elongata and Bacopa caroliniana were the least sensitive of the positive indicator species, as indicated by their broad distribution regardless of proximity to adjacent canals.

\section{Conclusion}

The HCAT has several potential applications including monitoring of vegetation community trends over time, among and between site comparisons, setting specific targets for desired conditions (e.g., restoration goals), and developing performance measures to evaluate progress toward stated goals and objectives. Potential targets could include specific index values or proportion of sites that have increasing trends in index value over time. Targets can also be applied to specific sites of interest. The level of success achieving stated targets can be assessed by developing performance measures relevant to developed targets. The HCAT tool also includes a model that can be used to predict impacts and changes to vegetation communities under conditions expected to result from proposed management actions, such as water management decisions for restoration projects. The HCAT is most powerful for assessing condition and informing management decisions if it is incorporated into a robust monitoring program that includes monitoring of drivers of habitat plant communities. However, even in the absence of additional monitoring strategies, the HCAT provides valuable information that can be incorporated into development of effective management and operations strategies.

The described approach could be modified for other areas outside of Florida and the Everglades to expand monitoring capabilities and effective management of protected areas. Initial development of the HCAT requires identification of indicator species with $\mathrm{CC}$ values that are available or can be developed. However, once species are selected and validated, surveys can be done quickly with minimal effort. Selected taxa should be easy to identify for minimally trained staff, represent a range of $\mathrm{CC}$ values, and include both common desirable and undesirable species based on conservation or restoration goals. In the northern Everglades, species were selected to indicate level of impact (hydrology; water quality) and to measure progress toward restoring the northern Everglades based on their historic range and ecological niches. In this case, familiarity with the habitat and different levels of impact was used for initial selection of species included in the modified FQI. However, other methods have been used to select species monitored for use in other indices, such as developing and applying an index of identification difficulty to highlight species that are relatively simple to identify (Chamberlain and Brooks 2016). Modified FQAs, such 
as the HCAT, should be verified using other available measures of habitat condition (such as water quality parameters) and, as with any monitoring program, should be re-evaluated periodically to ensure goals and stressors have not significantly changed. Once developed for a specific geographic area, the HCAT can be used to inform management decisions, establish specific target conditions, monitor cumulative impacts to habitat quality, and/or develop performance measures for evaluating progress toward goals.

Acknowledgments The authors would like to acknowledge the contributions of SFWMD staff, particularly Kristin Larson, Matthew Powers, Brad Robbins, Robert Shuford III, and Brent Warner as they provided data and technical assistance in developing vegetation sampling methods. We would also like to acknowledge Matthew Harwell, Steven Henry, and anonymous reviewers for valuable editorial comments that improved this manuscript.

Availability of data and material Data available on request from the authors.

\section{Code availability N/A}

Authors' contributions REG collected field data. DDS provided statistical analysis as well as figures and tables. All authors contributed to method and manuscript development.

Funding information This work was funded by the US Fish and Wildlife Service and Department of Interior.

\section{Compliance with ethical standards}

Conflict of interest Authors are employed by the Department of Interior within the US Fish and Wildlife Service and National Park Service.

Disclaimer The findings and conclusions in this article are those of the author(s) and do not necessarily represent the views of the US Fish and Wildlife Service.

\section{References}

Andreas, B. K., Mack, J. J., \& McCormac, J. J. (2004). Floristic quality assessment index (FQAI) for vascular plants and mosses for the state of Ohio. Columbus, Ohio: Ohio Environmental Protection Agency, Division of Surface Water, Wetland Ecology Group.

Bernhardt, C. E., \& Willard, D. A. (2009). Response of the Everglades ridge and slough landscape to climate variability and 20th-century water management. Ecological Applications, 19, 1723-1738.
Bernhardt, C. E., Brandt, L. A., Landacre, B., Marot, M. E., \& Willard, D. A. (2013). Reconstructing vegetation response to altered hydrology and its use for restoration, Arthur R. Marshall Loxahatchee National Wildlife Refuge. Florida. Wetlands, 33(6), 1139-1149.

Bourdaghs, M., Johnston, C. A., \& Regal, R. R. (2006). Properties and performance of the floristic quality index in Great Lakes coastal wetlands. Wetlands, 26(3), 718-735.

Bourdaghs, M. (2012). Development of a rapid floristic quality assessment. St. Paul, MN: Minnesota Pollution Control Agency.

Brown, M., Cohen, M., Bardi, E., \& Ingwersen, W. (2006). Species diversity in the Florida Everglades, USA: A systems approach to calculating biodiversity. Aquatic SciencesResearch Across Boundaries, 68(3), 254-277.

Busch, D. E., Loftus, W. F., \& Bass Jr., O. L. (1998). Long-term hydrologic effects on marsh plant community structure in the southern Everglades. Wetlands, 18(2), 230-241.

Chamberlain, S. J., \& Brooks, R. P. (2016). Testing a rapid floristic quality index on headwater wetlands in Central Pennsylvania, USA. Ecological Indicators, 60, 1142-1149.

Cohen, M. J., Carstenn, S., \& Lane, C. R. (2004). Floristic quality indices for biotic assessment of depressional marsh condition in Florida. Ecological Applications, 14(3), 784-794.

Cretini, K. F., Visser, J. M., Krauss, K. W., \& Steyer, G. D. (2012). Development and use of a floristic quality index for coastal Louisiana marshes. Environmental Monitoring and Assessment, 184, 2389-2403.

Davis, S., \& Ogden, J. (1994). The Everglades: The ecosystem and its restoration. Boca Raton, FL: St. Lucie Press.

Doherty, S., Cohen, M., Line, L., \& Surdick, J. (2000). Biological criteria for inland freshwater wetlands in Florida: A review of technical \& scientific literature (1990-1999): Gainesville, University of Florida. Technical report prepared for the U.S: Environmental Protection Agency.

Francis, C. M., Austen, M. J. W., Bowles, J. M., \& Draper, W. B. (2000). Assessing floristic quality in southern Ontario woodlands. Natural Areas Journal, 20, 66-77.

Gardner, M. (2014). Community ecology: Analytical methods using $R$ and Excel. Exeter: Pelagic Publishing.

Gibble, R. E., Surratt, D., Kapsch, M., \& Martin, M. (2013). Relating vegetation structure to water quality in the a.R.M, Loxahatchee national wildlife refuge. Broward County, FL: Presented at the Society for Freshwater Science Annual Meeting.

Godfrey, R.K., \& Wooten, J.W. (1981). Aquatic and wetland plants of the Southeastern United States. Dicotyledons. Athens: University of Georgia Press.

Gross, J., \& Ligges, U. (2012). Nortest: Tests for normality. R package version 1.0-2. Available at: http://CRAN.R-project. org/package=nortest.

Harwell, M. C., Surratt, D. D., Barone, D. M., \& Aumen, N. G. (2008). Conductivity as a tracer of agricultural and urban runoff to delineate water quality impacts in the northern Everglades. Environmental Monitoring and Assessment, 147(1-3), 445-462.

Hagerthey, S. C, Newman S., Rutchey, K., Smith, E.P., Godin, J. (2008). Multiple regime shifts in a subtropical peatland: Community-specific thresholds to eutrophication. Ecological Monographs, v78, pg 547-565. 
Herman, K. D., Master, L. A., Penskar, M. R., Reznicek, A. A., Wilhelm, G. S., \& Brodowicz, W. W. (1997). Floristic quality assessment: development and application in the State of Michigan (USA). Conservation Tools, Natural Areas Journal, 17, 265-279.

Johnston, C. A., Ghioca, D. M., Tulbure, M., Bedford, B. L., Bourdaghs, M., Frieswyk, C. B., Vaccaro, L., \& Zedler, J. B. (2008). Partitioning vegetation response to anthropogenic stress to develop multi-taxa wetland indicators. Ecological Applications, 18(4), 983-1001.

King, R. S., Richardson, C. T., Urban, D. L., \& Romanowicz, E. A. (2004). Spatial dependency of vegetation: Environment linkages in an anthropogenically influenced wetland ecosystem. Ecosystem, 7(1), 75-97.

Kushlan, J. A. (1990). Freshwater marshes. In Ecosystems of Florida (pp. 324-363). Orlando, FL: The University of Central Florida Press.

Lane, C. R., Brown, M. T., Murray-Hudson, M., \& Vivas, M. B. (2003). Report submitted to the Florida Department of Environmental Projection: The wetland condition index (WCI): Biological indicators of wetland condition for isolated depressional herbaceous wetlands in Florida. Gainesville, FL: University of Florida. https://ufdc.ufl.edu/AA00004282 /00001.

Larsen, L., Harvey, J., \& Crimaldi, J. (2007). A delicate balance: Ecohydrological feedbacks governing landscape morphology in a lotic peatland. Ecological Monographs, 77(4), 591614.

Larsen L., Aumen, N., Bernhardt, C., Engel V., Givnish, T., Hagerthey, S., Harvey, J., Leonard, L., McCormick, P., McVoy, C., Noe, G., Nungesser, M., Rutchey, K., Sklar, F., Troxler, T., Volin, J., \& Willard, D. (2010). Recent and historic drivers of landscape change in the Everglades ridge, slough, and tree island mosaic. Critical Reviews in Environmental Science and Technology, v41 (S1), 1-38.

Lopez, R. D., \& Fennessy, M. S. (2002). Testing the floristic quality assessment index as an indicator of wetland condition. Ecological Applications, 12, 487-497.

Marchant, B. P., Newman, S., Corstanje, R., Reddy, K. R., Osborne, T. Z., \& Lark, R. M. (2009). Spatial monitoring of a non-stationary soil property: Phosphorus in a Florida water conservation area. European Journal of Soil Science, 60, 757-769.

Matthews, J. W. (2003). Assessment of the floristic quality index for use in Illinois, USA, wetlands. Natural Areas Journal, 23, 53-60.

McCormick, P. V. (2010). Soil and periphyton indicators of anthropogenic water-quality changes in a rainfall-driven wetland. Wetlands Ecology and Management, 19, 19-34.

McCormick, P. V., Harvey, J. W., \& Crawford, E. S. (2011). Influence of changing water sources and mineral chemistry on the Everglades ecosystem. Critical Reviews in Environmental Science and Technology, 41(S1), 28-63.

Meselhe, E. A., Arceneaux, J. C., \& Waldon, M. G. (2010). Water budget model for a remnant northern Everglades wetland. Journal of Hydraulic Research, 48, 100-105.

Miao, S. L., \& Zou, C. B. (2012). Effects of inundation on growth and nutrient allocation of six major macrophytes in the Florida Everglades. Ecological Engineering, 42, 10-18.

Miller, S. J., \& Wardrop, D. H. (2006). Adapting the floristic quality assessment index to indicate anthropogenic disturbance in Central Pennsylvania wetlands. Ecological Indicators, 6, 313-326.

Mortellaro, S., Barry, M., Gann, G., Zahina, J., Channon, S., Hilsenbeck, C., Scofield, D., Wilder, G., \& Wilhem, G. (2009). Coefficients of conservatism values and the floristic quality index for the vascular plants of South Florida. South Florida Ecological Services Field Office, Vero Beach, Florida, pp78.

Newman, S., Grace, J. B., \& Koebel, J. W. (1996). Effects of nutrients and hydroperiod on Typha, Cladium, and Eleocharis: Implications for Everglades restoration. Ecological Applications, 6, 774-783.

Nichols, J. D., Perry, J. E., \& DeBerry, D. A. (2006). Using a floristic quality assessment technique to evaluate plant community integrity of forested wetlands in southeastern Virginia. Natural Areas Journal, 26(4), 360-369.

Ogden, J. C. (2005). Everglades ridge and slough conceptual ecological model. Wetlands, 25(4), 810-820.

Porter, J. W., \& Porter, K. G. (2002). The Everglades, Florida bay, and coral reefs of the Florida keys: An ecosystem sourcebook. Boca Raton: FL. CRC Press.

R Core Team. (2014). $R$ : A language and environment for statistical computing. Vienna, Austria: R Foundation for Statistical Computing Available at: http://www.R-project.org/.

Reddy, K. R., \& Osborne, T. (2007). Water conservation areas transect soil sampling. Institute of Food and Agricultural Sciences. Gainesville: University of Florida.

Richardson, J. R., Bryant, W. L., Kitchens, W. M., Mattson, J. E., \& Pope, K. R. (1990). An evaluation of refuge habitats and relationships to water quality, quantity, and hydroperiod: $A$ synthesis report. Florida cooperative fish and wildlife research unit. Gainesville, Florida: University of Florida.

Rooney, T. P., \& Rogers, D. A. (2002). The modified floristic quality index. Natural Areas Journal, 22(4), 340-344.

Rutchey, K., Schall, T. N., Doren, R. F., Atkinson, A., Ross, M. S., Jones, D. T., Madden, M., Vilchek, L., Bradley, K. A., Snyder, J. R., Burch, J. N., Pernas, T., Witcher, B., Pyne, M., White, R., Smith III, T. J., Sadle, C. S., Patterson, M. E, \& Gann, G. D. (2006). Vegetation Classification for South Florida Natural Areas. U.S. Department of the Interior, U.S. Geological Survey. Open-File Report 2006-1240.

Smith, R. D., Ammann, A., Bartoldus, C., \& Brinson, M. M. (1995). An approach for assessing wetland functions using hydrogeomorphic classification, reference wetlands, and functional indices, WRP-DE-9. Waterways Experiment Station, U.S. Vicksburg, MS, USA: Army Corps of Engineers.

Snedecor, G. Q., \& Cochran, W. Q. (1989). Statistical methods (8th ed.). Ames, Iowa: Iowa State University Press.

South Florida Water Management District, DBHYDRO database, accessed February 2, 2018, at http://www.sfwmd.gov/ portal/page/portal/xweb\%20environmental\%20monitoring/ dbhydro\%20application.

South Florida Water Management District (2010). Field sampling quality manual. Water Quality Monitoring Division, Restoration Sciences Department, South Florida Water Management District. SFWMD-FIELD-QM-001-06.

Surratt, D. D., Waldon, M. G., Harwell, M. C., \& Aumen, N. G. (2008). Time-series and spatial tracking of polluted canal water intrusion into wetlands of a National Wildlife Refuge in Florida, USA. Wetlands, 28(1), 176-183. 
Taft, J. B., Wilhelm, G. S, Ladd, D. M., \& Masters, L. A. (1997). Floristic quality assessment for vegetation in Illinois, a method for assessing vegetation integrity. Erigenia, 15, 3-95.

Taylor, W. A. (2001). Change-point analysis: A powerful new tool for detecting changes. http://www.variation.com/cpa/.

U.S. Environmental Protection Agency. (2002). Biological assessments and criteria: Crucial components of water quality programs, EPA 822-f-02-006. Washington DC, USA: U.S. Environmental Protection Agency.

Wang, H., Meselhe, E. A., Waldon, M. G., Surratt, D., Abdou, S., Chen, C., Harwell, M. C. (2008). Compartment delineation for a wetland water quality model in the Northern Everglades, Florida, USA. Journal of Environmental Hydrology, v16, paper 36.

Wang, H., Waldon, M. G., Meselhe, E.A., Arceneaux, J.C., Chen, C., \& Harwell, M.C. (2009). Surface water sulfate dynamics in the northern Florida Everglades. Journal of Environmental Quality, 38, pg 1-8.

Wilhelm, G. \& Masters, L. (2006a). Floristic quality assessment and computer applications: Iowa database from Pauline Drobney and others. Conservation Research Institute.

Wilhelm, G. \& Masters, L. (2006b). Floristic quality assessment and computer applications: Kentucky database from Margaret Shea and others. Conservation Research Institute.

Zar, J. H. (1999). Biostatistical analysis (4th ed.). Inc, Upper Saddle River, New Jersey: Prentice-Hall.

Publisher's note Springer Nature remains neutral with regard to jurisdictional claims in published maps and institutional affiliations. 